\title{
ANALISIS DNA MITOKONDRIA SWAB EARPHONE SEBAGAI BAHAN ALTERNATIF PEMERIKSAAN IDENTIFIKASI
}

\author{
Ahmad Yudianto ${ }^{1,2,3}$, Yeti Eka Sispitasri ${ }^{1.3}$, Nola Margaret ${ }^{1}$ \\ ${ }^{1}$ Departemen Ilmu Kedokteran Forensik dan Medikolegal Fakultas Kedokteran Universitas Airlangga \\ ${ }^{2}$ Laboratorium Human Genetic Institute Tropical Disease Universitas Airalangga \\ ${ }^{3}$ Program Studi Magister Ilmu Forensik Sekolah Pascasarjana Universitas Airlangga \\ email : yudi4n6sby@yahoo.co.id
}

\begin{abstract}
Identification include fingerprint, property, medical, dental, serologic and exclusion methods. In the development, identification methods led to molecular forensics, a new field of science evolving since the 1980s, known as DNA fingerprinting.

Blood spots/bloods, semen spots, vaginal swabs, buccal swabs and bones are specimens widely used in DNA assay for identification. In addition to these specimens, the last objects often used by the perpetrators/victims can be used, such as hearing aids (headsets/earphones). In its use, earphones are attached to the outer ear skin; thus, the earwax is suspected to adhere to the device. To date, in Indonesia personal identification is performed through swabs of earphones/headsets using the DNA profiling method. In particular, mitochondrial DNA has not been widely used for identification.

The present study was of laboratory experimental. Earphones which have been used for 3 days were placed in room temperature for $1,7,14$ and 20 days.

Results showed that the environmental factor of exposure duration had an effect of a significant decrease in the levels of DNA from day 1 to day 20. Only 126-bp mtDNA (HVS II) was detected on the samples of day 1 and continued with sequencing. Mitochondrial DNA has better durability and relatively higher number of copies than those of nuclear DNA. This leads to greater possibility of success in amplification, given the higher number of mitochondrial DNA copies and the fact that mitochondrial DNA is a single locus that allows recombination.
\end{abstract}

Keywords: Earphone swabs, identification, mtDNA

\section{Pendahuluan}

Metode identifikasi dalam kedokteran forensik yakni diantaranya sidik jari (daktiloskopi), properti, medis, gigi geligi, serologi dan metode eksklusi. Sidik jari dan gigi-geligi merupakan metode paling spesifik untuk identifikasi personal [1].

Dalam perkembanganya metode identifikasi mengarah pada forensik molekuler. Forensik molekuler adalah suatu bidang ilmu yang baru berkembang sejak tahun 1980an metode yang lebih dikenal dengan sebutan : fingerprinting DNA. Metode ini pertamakali diperkenalkan oleh Jefreys pada tahun 1985, merupakan bagian bidang kedokteran yang memanfaatkan pengetahuan ilmu kedokteran dan

biologi pada tingkat molekul atau DNA (Deoxyribonucleid acid) [2].

DNA merupakan unit keturunan terkecil dan terdapat semua mahluk hidup mulai dari mikroorganisme sampai organisme tingkat tinggi seperti manusia, hewan dan tanaman. Menurut Notosoehardjo (2001), tiap jaringan mempunyai kandungan DNA yang berbeda-beda tergantung struktur serta komposisi selnya. Jaringan dengan banyak sel berinti dan sedikit jaringan ikat umumnya mempunyai kadar DNA tinggi. Pemilihan organ yang akan diisolasi DNA guna analisis kasus forensik sangatlah penting, kadangkala keadaan yang sudah membusuk lanjut atau hanya tinggal tulang belulang. 
Hukum Mendel dalam pewarisan sifat dinyatakan bahwa spesimen/sampel pemeriksaan DNA didapatkan dari seluruh bagian dari tubuh manusia oleh karena setiap sel dalam tubuh seseorang memiliki rangkaian DNA identik. Kandungan materi genetik anak pada dasarnya menerima jumlah material genetika yang sama dari ibu dan ayah kandungnya yakni masing-masing 50\% [2].

Selama ini spesimen yang banyak dipakai dalam pemeriksaan DNA dalam mengidentifikasi, adalah spesimen yang bercak darah/darah, bercak semen, vaginal swab, buccal swab dan tulang [3]. Di tempat kejadian perkara/TKP akan didapatkan trace evidence biologi. Selain trace evidence tersebut diantara benda-benda yang sering digunakan pelaku atau korban terakhir kalinya. Satu diantaranya yakni alat bantu dengar handphone yang sekarang lagi marak yakni headset atau earphone. Headset/earphone merupakan alat elektronika audio, yang digunakan dalam mendengar suara handphone atau MP3. Dalam penggunaannya earphone menempel pada kulit telinga bagian luar sehingga diduga adanya serumen yang menempel pada alat tersebut. Sebelumnya di Jepang telah dilakukan penelitian tentang hal tersebut, Seo Y, et al (2002) dalam penelitiannya yaitu melakukan identifikasi forensik melalui bahan serumen yang melekat pada earphone yang digunakan oleh pelaku kejahatan. Hanya saja sampai saat ini belum banyak penelitian yang secara spesifik menjelaskan efektivitas penggunaan swab earphone untuk digunakan sebagai bahan identifikasi. .

Maka perlu dikembangkan pemeriksaan benda-benda yang didapat dari tempat kejadian perkara salah satunya alat earphone tersebut. Sehingga penelitian ini diharapkan 10 dapat memberi jawaban pada hal-hal yang berkaitan dengan penggunaan spesimen yang berasal dari serumen yang menempel pada earphone / swab earphone dalam hal identifikas forensik khususnya identifikasi jenis kelamin. Sehingga penemuan barang-barang yang di tempat kejadian perkara akan memberi kontribusi besar dalam mengungkap tindak kejahatan [1], [3].

$$
\text { Identifikasi DNA yang }
$$

melibatkan kromosom somatik, pembanding yang digunakan adalah ayah dan ibu. Sedangkan pada pemeriksaan DNA mitokondria, pembanding yang digunakan adalah kerabat dalam satu garis keturunan ibu. Berbagai variasi pembanding dapat digunakan sesuai jenis kasus, misalnya dapat digunakan pembanding kakeknenek, sepupu dan lain-lain, namun tentu saja analisis data yang digunakan sedikit berbeda [4].

Adapun beberapa perbedaan antara DNA mitokondria $(m t D N A)$ manusia dari genom inti, yakni $m t D N A$ hanya diturunkan lewat jalur ibu tanpa rekombinasi (maternal inherited). Sehingga $m t D N A$ sel anak seluruhnya dari ibu [ovum/sel telur] sedangkan sel sperma sama sekali tidak berkontribusi [5]. Sistem pewarisan tersebut berguna dalam penentuan hubungan kekerabatan, studi evolusi dan migrasi global manusia modern, bidang forensik dan identifikasi penyakit genetik [6].

Sampai saat ini di Indonesia identifikasi personal melalui $s w a b$ pada earphone/headset dengan metode analisis DNA (DNA Profiling) khususnya melalui DNA mitokondria belum banyak dilakukan, sehingga penelitian ini diharapkan dapat memberi jawaban pada hal-hal yang terkait dengan efektivitas penggunaan swab earphone sebagai bahan identifikasi forensik. 


\section{Bahan dan Alat}

Bahan Penelitian : swab earphone, DNAzol Reagent, Larutan $100 \%$ \& 70 $\%$ ethanol, PCR Mix, Nuclease Free water, urutan nukleotida primer mtDNA 126 bp ( nt 34-159. HVS II) ( AFDIL , Gabriel et al, 2001) : 5'- GGG AGC TCT CCA TGC ATT TGG TA-3' \& 5'- AAA TAA TAG GAT GAG GCA GGA ATC-3'

\section{Metode}

Jenis penelitian ini yakni observasional laboratoris. Earphone yang telah digunakan dalam 3 hari, diletakkan suhu ruang rentang waktu 1 , 7, 14 dan 20 hari. melalui daerah $D$ Loop DNA mitokondria 126 bp ( nt 34159. HVS II), dengan rancangan penelitian cross sectional survey.

Subyek penelitian ini yakni alat earphone yang telah digunakan/ menempel liang telinga selama 3 hari dan disimpan selama 1 hari, 7 hari, 14 haridan20 hari.(@2 sampel)

\section{Hasil dan Pembahasan}

Penelitian ini diawali dengan perlakuan pada sampel yakni 8 buah alat earphone yang telah digunakan/menempel di liang telinga selama 3 hari dan selanjutnya alat tersebut di simpan pada suhu kamar masing-masing dalam waktu : 1 hari , 7 hari, 14 hari dan 20 hari.

Kemudian dilanjutkan masingmasing kelompokwaktu (@ 2 buah alat earphone) dengan ekstraksi/isolasi DNA sampel dari swab earphone dengan metode DNAzol. Hasil ekstraksi DNA sampel tersebut dilanjutkan dengan pengukuran kadar DNA sampel dengan menggunakan UV-Visible Spectrophotometer pada panjang gelombang $260 \mathrm{~nm}$ ( $\lambda$ 260). Hasil pengukuran kadar DNA setelah isolasi DNA dari swab earphone sebelum dilakukan amplifikasi PCR (Polymerase Chain Reaction) sebagai berikut:

Tabel 1. Kadar DNA pada sampel

\begin{tabular}{|c|c|c|c|}
\hline \multicolumn{2}{|c|}{ Sampel } & $\begin{array}{c}\text { Kadar DNA } \\
(\square \mathbf{g} / \mathbf{m l})\end{array}$ & $\begin{array}{c}\text { Rerata kadar } \\
(\square \mathbf{g} / \mathbf{m l})\end{array}$ \\
\hline \multirow{2}{*}{ Hari ke 01} & 1 & 23.24 & \multirow{2}{*}{21.67} \\
\hline & 2 & 20.09 & \\
\hline \multirow{2}{*}{ Hari ke 07} & 1 & 16.05 & \multirow{2}{*}{14.70} \\
\hline & 2 & 13.35 & \\
\hline \multirow{2}{*}{ Hari ke 14} & 1 & 7.25 & \multirow{2}{*}{8.14} \\
\hline & 2 & 9.03 & \\
\hline \multirow{2}{*}{ Hari ke 20} & 1 & 8.20 & \multirow{2}{*}{6.60} \\
\hline & 2 & 5.01 & \\
\hline
\end{tabular}




\section{Grafik Kadar DNA sampel}

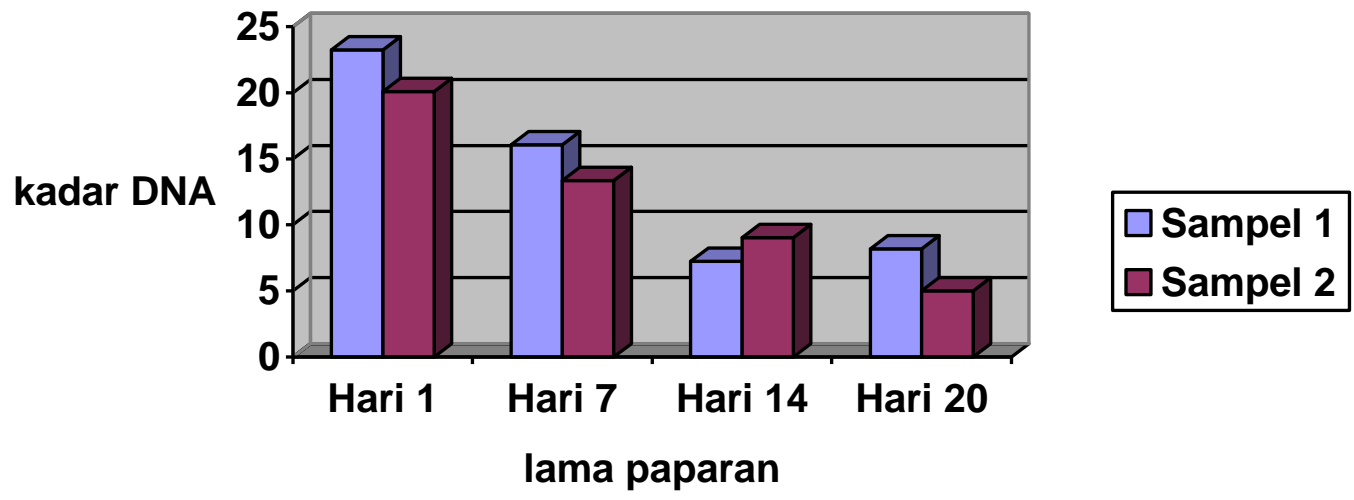

Dari grafik diatas, adanya penurunan kadar DNA dari swab earphone pada sampel yang terpapar lama waktu. Semakin lama waktu yang dipaparkan semakin turun kadar DNAnya, yakni rerata pada hari ke 1: $21,50 \mu \mathrm{g} / \mathrm{ml}$, hari ke $7: 14,70 \mu \mathrm{g} / \mathrm{ml}$, hari ke $14: 8,14 \mu \mathrm{g} / \mathrm{ml}$ dan hari ke 20 : $6,60 \square \mathrm{g} / \mathrm{ml}$.

Proses amplifikasi Polymerase Chain Reaction (PCR) yakni diawali dengan penyiapan DNA template

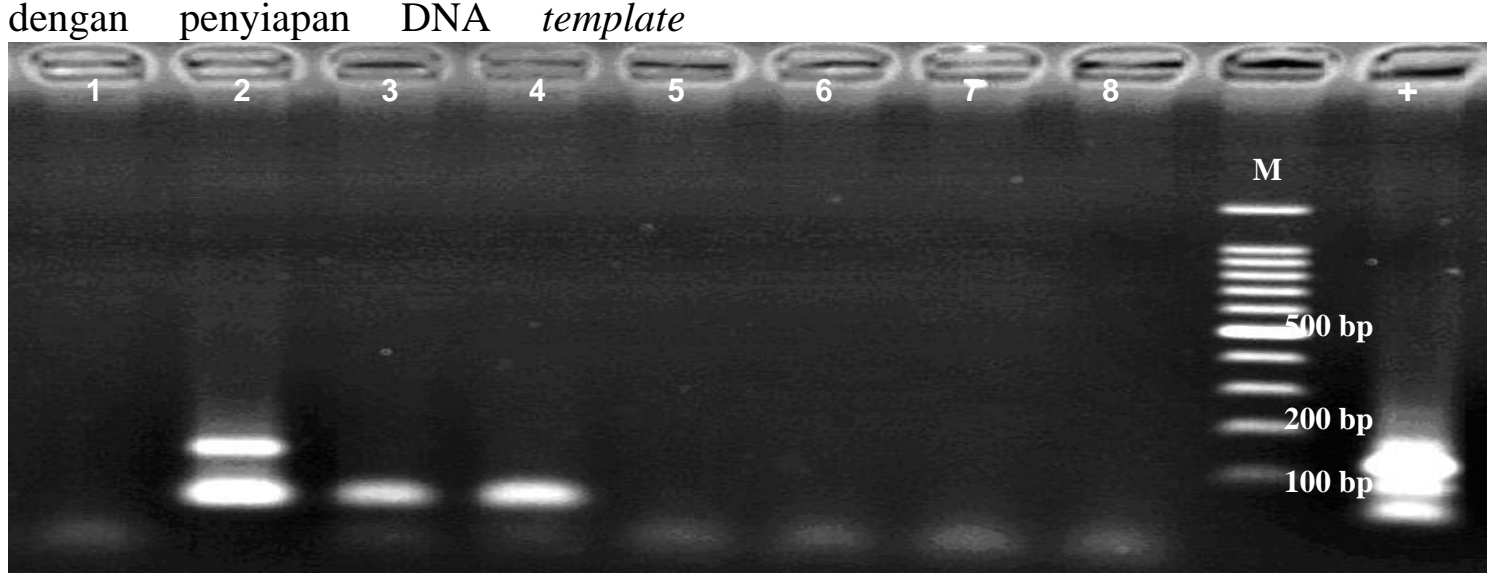

Gambar 1. Hasil visualisasi hasil PCR 126 bp sampel swab earphone, (M) marker, $(+)$ kontrol positif, $(1,2)$ : sampel hari $1, \quad(3,4)$ : sampel hari $7,(5,6)$ : sampel hari 14 , $(7,8)$ : sampel hari 20

Dalam gambar 1 diatas menunjukkan munculnya satu pita pada $126 \mathrm{pb}$ bahwa pasangan primer yang digunakan bersifat spesifik hanya menempel pada posisi yang diharapkan 12 melalui proses lisis sel dari swab earphone dengan menggunakan kit ekstraksi (DNAzol). Hasil ekstraksi/isolasi DNA tersebut ternyata mampu menghasilkan lisat sel yakni berupa DNA yang siap untuk digunakan sebagai template PCR. Proses amplifikasi PCR tersebut berhasil memperoleh satu band berukuran 126 bp seperti pada gambar dibawah ini. 
dengan elektroforesis gel agarosa $1,2 \%$ $(\mathrm{b} / \mathrm{v})$. Hasil visualisasi tersebut menunjukkan hanya sampel 2 yang masih dapat deteksi positif (+).

Fragmen sekuensing pada daerah 126bp D-loop mtDNA dari sampel swab earphone dilakukan menggunakan Automatic DNA Sequencer yang berdasarkan pada metode Dye Terminator Labeling. Sequencing 126bp fragmen hasil PCR dilakukan secara langsung tanpa melalui proses kloning [direct sequencing].
Metode ini prosesnya cepat dan hasilnya merupakan urutan nukleotida dominan dari DNA hasil amplifikasi PCR. Untuk penentuan urutan nukleotida produk PCR yang berukuran 126 bp dalam reaksi sekuensing digunakan primer forward [M1]. Penelitian ini menunjukkan keberhasilan dalam menentukan urutan nukleotida daerah D-Loop mtDNA dari sampel seperti terlihat pada gambar dibawahini.

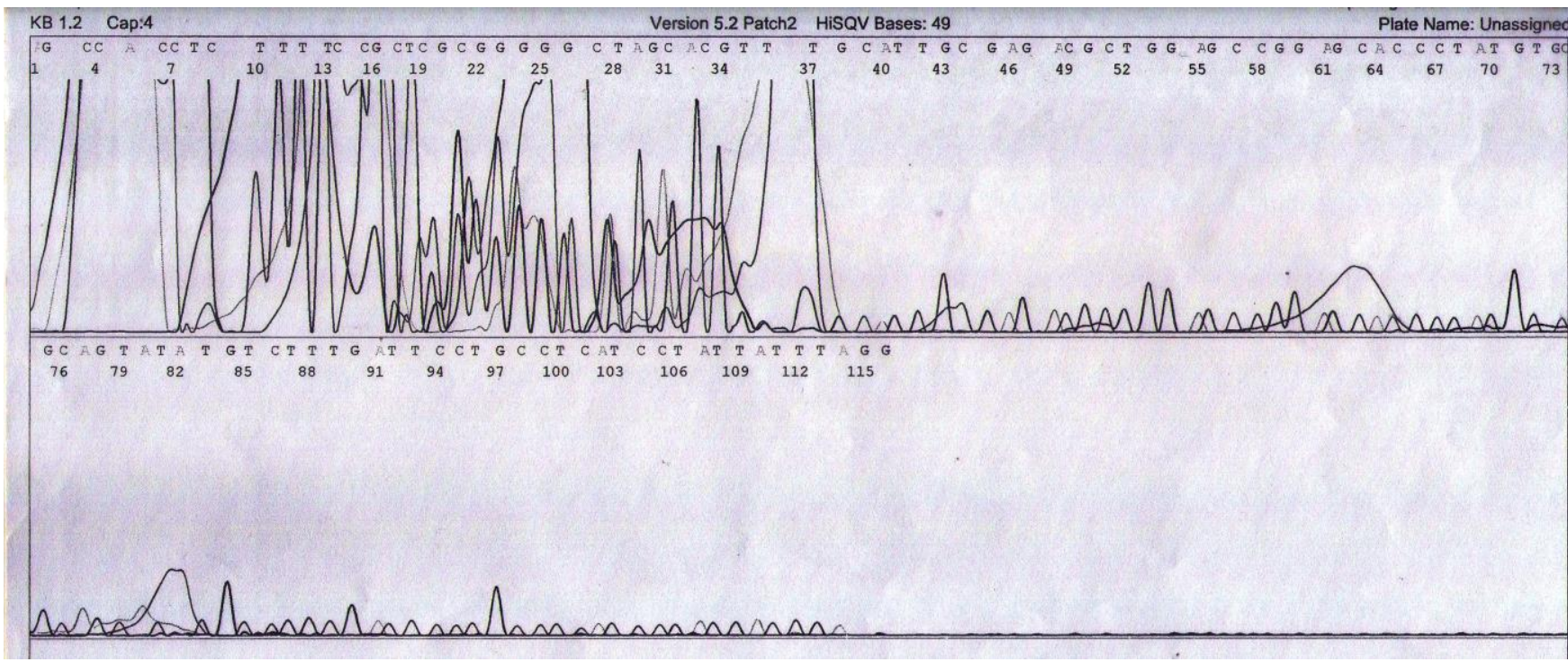

Gambar 2. Hasil Sekuensing sampel

Gambar 2 menunjukkan elektroforegram sekuensing, adanya perbedaan warna garis, yakni warna hitam untuk guanin $(G)$, warna biru untuk Cytosin (C), warna merah untuk tymin (T) dan warna hijau untuk adenin (A).

Dari hasil penelitian ini efek lingkungan dalam hal temperature serta lama paparan terhadap efek tersebut dalam penelitian ini membuktikan adanya pengaruhnya terhadap pengukuran kadar DNA yang terkandung. Hal tersebut terlihat dari hasil pengukuran kadar DNA melalui
Spektrofotometri menunjukkan penurunan kadar pada sampel-sampel DNA swab earphone cukup signifikan dari hari ke 1 sampai ke 20. Hanya pada sampel hari ke 1 yang masih menunjukkan terdeteksi pada mtDNA 126 bp HVS II serta dilanjutkan sekuensing..

Hasil penelitian ini tersebut juga menunjukkan efek lingkungan dalam hal lama waktu paparan terhadap efek tersebut dalam penelitian ini membuktikan adanya pengaruhnya terhadap pengukuran kadar DNA yang terkandung. Hal tersebut terlihat dari 
hasil pengukuran kadar DNA melalui UV Spektrofotometri menunjukkan tempat dengan kelembaban tinggi dari hari $1,7,14$ sampai hari ke 20 terdapat adanya penurunan yang cukup signifikan. Faktor lingkungan tersebut menyebabkan, DNA mengalami kerusakan. Kerusakan tersebut bisa terjadi cepat atau lambat, tergantung yang mempengaruhi dan waktu paparan. Ada 2 tipie Kerusakan DNA yakni kerusakan dari faktor dalam, misal reactive oxygen species (ROS) dan Kerusakan dari faktor luar, misal suhu, kelembaban dan lain sebagainya

Menurut Anderson et.al (1999), ketahanan DNA mitokondria lebih baik jika dibandingkan DNA inti hal tersebut memiliki jumlah relatif banyak sehingga memiliki kemungkinan keberhasilan dalam proses amplifikasi lebih besar, mengingat jumlah copy DNA mitokondria lebih banyak.. Mitokondra DNA memiliki jumlah copy yang lebih banyak sekitar 500-2000 copy per sel, dibandingkan DNA inti yang hanya 2 copy per sel dan juga DNA mitokondria merupakan lokus tunggal sehingga adanya rekombinasi [7].

Sehingga DNA mitokondria mempunyai sifat power of discrimination lebih rendah dibandingkan DNA inti. Sehingga dengan demikian DNA mitokondria merupakan alternatif ketika dihadapkan pada kondisi DNA inti yang terdegradasi kompleks atau parah. Namun bila penggunaan primer standar pada STR tidak mampu mendeteksi, maka alternatifnya melakukan redisain primer dengan mengurangi amplicon size sebelum penggunaan mtDNA..

Pada earphone yang telah digunakan dalam 3 hari diletak pada suhu kamar selama maksimal 20 hari (sesuai KUHAP lama masa penahanan 14 penurunan kadar pada sampel bercak urine yang tersimpan di suhu kamar dan dalam proses penydikan). Hasil penelitian ini menunjukkan lingkungan [suhu kamar] berpengaruh terhadap perubahan kadar DNA swab earphone seperti nampak pada tabel 1 tersebut. Dibuktikan dalam uji statistik menunjukkan signifikan $\mathrm{p}>0.05$ (sig.0.34), pengaruh lingkungan terhadap penurunan kadar DNA tersebut..

\section{Kesimpulan}

Penelitian menyimpulkan sebagai berikut :

1. Terdapat faktor eksternal yakni lingkungan dan lama paparan mempengaruhi kuantitas dan kualitas DNA dari swab eraphone, nanum masih dapat menjadi bahan alternatif dalam identifikasi forensik.

2. Dari hasil PCR hanya 1 sampel hari ke 1 yang masih meunjukkan terdeteksi pada mtDNA HVS II 126 bp (nt nt 34-159) dan hasil sekensing juga. Sedangkan sampel hari 7,14 dan 20 tidak terdeteksi dengan elektroforese agarose $2 \%$.

3. Pemeriksaan mtDNA dari swab earphone hanya bisa dilakukan sehari setelah alat tersebut tertinggal didalam ruang terbuka.

\section{DAFTAR PUSTAKA}

[1] Idries, A.M, 1997, Pedoman Ilmu Kedokteran Forensik, Edisi pertama, Jakarta, Penerbit Binarupa Aksara

[2] Lewis R, 2001,Human Genetics Conception and Application, $2^{\text {nd }} \mathrm{Ed}$ Wm.C.Brown Publishers, Toronto, page139-180

[3] Notosoehardjo I,2001,DNA Forensics ;Paternity test, Past, Present,andFuture,J.For.Scien,VIII, pp 34-45. 
[4] Syukriani Y, 2012. DNA Forensik. PT Sagung Jakarta.

[5] Butler,JM, 2003, Forensic DNA Typing, Academic Press, SandiegoFlorida, page 28-30, page 59-96.

[6] Wallace, D.C. 1997, Mitochondrial DNA variation in human evolution, degenerative disease and aging. American Journal of Human Genetic.57,201-223.

[7] Muladno, 2002, Seputar tehnologi rekayasa genetik, Edisi pertama, Bogor, Pustaka.
[8] Anderson,S.,et al.1999. Sequence and organization of the human mitochondrial genom, Nature, 290,457-465.

[9] Yasuhisa Seo, Taketo Uchiyama, Hirokazu Matsuda, Kenshi Shimizu, Yasunari Takami, Tasuo Nakayama, Keiichi Takhama, 2002, Mitochondrial DNA and STR Typing of Matter adhering to an earphone, Journal of Forensic Sci; 47(3):605-608. 